\title{
PENINGKATAN HASIL BELAJAR PENDIDIKAN KEWARGANEGARAAN DENGAN MENGGUNAKAN METODE BERMAIN PERAN KELAS IV SEKOLAH DASAR KABUPATEN TANAH TIDUNG
}

\author{
Lucky Susilo \\ Pendidikan Dasar, Universitas Negeri Jakarta \\ luckysusilo@gmail
}

\begin{abstract}
This research is to improve student learning outcomes of civic education about the hero. This research was conducted in SDN Sesayap Tana Tidung, with 23 students as research subjects. This research is an action using Kemmis and McTaggart models in two cycles. Each cycle consists of planning, action, observation, and reflection. The results showed an increase in student learning outcomes of civic education, the hero mainly about understanding the meaning and involve symbols in understanding Pancasila Pancasila principles completely. This was evidenced by the increase in student learning outcomes Civics of my heroes from the $50 \%$ of students complete with the average score was 69 in the first cycle, increased to $80 \%$ of students complete with the average score was 77 in the second cycle. Activities of teachers and students through role playing method attained mastery learning $(100 \%)$ at the end of the cycle. The conclusion of this study indicate that the use of methods Role Playing makes the students more active in learning appropriate to their developmental age.
\end{abstract}

Keywords: The Students' Study Result Of Civic Education, Role Playing Method Action Research

\begin{abstract}
Abstrak: Penelitian ini untuk meningkatkan hasil belajar siswa dari pendidikan kewarganegaraan tentang pahlawan . Penelitian ini dilaksanakan di SDN Tana Tidung, dengan 23 siswa sebagai subyek penelitian. Penelitian ini merupakan penelitian tindakan dengan menggunakan Kemmis dan model McTaggart dalam dua siklus. Setiap siklus terdiri dari perencanaan, bertindak, observasi, dan refleksi. Hasilnya menunjukkan peningkatan hasil belajar siswa dari pendidikan kewarganegaraan, tentang pahlawan terutama tentang pemahaman makna dan melibatkan simbol prinsip pancasila dalam memahami pancasila benar-benar. Hal itu dibuktikan dengan meningkatnya hasil belajar siswa PKn tentang pahlawan saya dari 50\% siswa lengkap dengan skor rata-rata adalah 69 pada siklus I, meningkat menjadi $80 \%$ siswa lengkap dengan skor rata-rata adalah 77 pada siklus kedua. Kegiatan guru dan siswa melalui metode Role Playing dicapai belajar penguasaan (100\%) pada akhir siklus. Kesimpulan dari penelitian ini menunjukkan bahwa penggunaan metode Role Playing membuat siswa lebih aktif dalam belajar yang sesuai dengan perkembangan usia mereka.
\end{abstract}

Kata kunci: Pendidikan Kewarganegaraan, Role Playing Metode, Penelitian Tindakan 
Pendidikan harus mampu melakukan proses pematangan kualitas peserta didik yang dikembangkan dengan cara membebaskan peserta didik dari ketidaktahuan, ketidakmampuan, ketidakberdayaan, ketidakbenaran dan dari buruknya akhlak dan keimanan. Oleh karena itu, pendidikan mulai menyentuh manusia sejak dini termasuk di pendidikan sekolah dasar.

Harapan dari penerapan pembelajaran Pendidikan pancasila dan kewarganegaraan yaitu menekankan pada unsur pendidikan dan karakteristik peserta didik. Penekanan pembelajarannya bukan sebatas pada upaya memberikan sejumlah konsep yang besifat hafalan semata bagi peserta didik, tetapi lebih menekankan bagaimana siswa dapat menghargai kebersamaan dalam keberagaman sebagai anugerah Tuhan Yang Maha Esa di lingkungan rumah, sekolah dan masyarakat serta menunujukkan perilaku, disiplin, tanggung jawab, percaya diri, berani mengakui kesalahan, meminta maaf dan memberi maaf, sebagai perwujudan nilai dan moral pancasila.

Dalam proses melaksanakan pembelajaran Pendidikan pancasila dan kewarganegaraan yang baik, guru harus: 1) dapat menampilkan ciri-ciri kepribadian seperti empatik, peduli terhadap siswa, sabar, adil, terbuka serta dapat menjadi pendengar yang baik, 2) dapat menerapkan pembelajaran individual dan dapat memahami siswanya (kebutuhan, potensi, minat, karakteristik kepribadian dan latar belakangnya, 3) lebih banyak memberikan komentar dan umpan balik yang positif dari pada yang negatif, 4) dapat menghargai dan menghormati setiap pemikiran, pendapat dan keputusan setiap siswanya, 5) dapat menjadi penolong yang bisa diandalkan dan memberikan kepercayaan terhadap siswanya. Guru harus memahami perkembangan psikologi siswa sesuai usianya. Dalam hal ini, guru perlu memberi kesempatan kepada siswa untuk berpartisipasi dalam proses belajar mengajar, menguatkan upaya siswa untuk memelihara ketertiban dalam proses belajar mengajar dan memperhatikan aspek efektif murid. Guru yang kreatif pasti akan memperhatikan metode yang akan digunakan pada setiap mengajar diseuaikan dengan materi yang akan disampaikan, tidak terpaku pada satu metode.

Dalam kenyataan di lapangan, peneliti masih banyak menemui gaya mengajar yang monoton satu arah tanpa ada interaksi yang hidup. Guru hanya menggunakan metode yang umum yaitu duduk, dengar, catat, dan 
Peningkatan hasil belajar PKn

Lukcy Susilo

hafal. Metode yang digunakan guru cendrung satu arah dan hanya mengembangkan satu aspek pembelajaran yaitu kognitif. Kondisi penggunaan metode tersebut di atas pada akhirnya menyebabkan tujuan pada pelajaran tidak tercapai secara optimal. Dari hasil belajar siswa pun ditemukan fakta bahwa sebagian siswa masih belum mampu memenuhi kriteria minimal yang ditetapkan.

Dari pengamatan yang dilakukan peneliti pada siswa kelas IV SD Negeri 009 Sesayap Kabupaten Tana Tidung diketahui bahwa siswa kurang menyenangi pembelajaran Pendidikan pancasila dan kewarganegaraan, siswa kurang bersemangat dan kurang siap dalam mengikuti pelajaran karena dijejali dengan sekumpulan fakta dan konsep tanpa menggunakan pengetahuan yang dimilikinya. Selain itu siswa hanya menjadi pendengar setia dan mencatat hal-hal penting yang tertera dalam buku pelajaran tanpa mengerti penggunaannya dalam kehidupan kesehariannya.

Suharsimi Arikunto dkk (2013:57), mengemukakan Penelitian Tindakan Kelas merupakan penelitian yang dilakukan oleh guru, bekerja sama dengan peneliti (atau dilakukan oleh guru sendiri yang juga bertindak sebagai peneliti) di kelas atau di sekolah tempat ia mengajar dengan penekanan pada penyempurnaan atau peningkatan proses dan praktis pembelajaran.

Ekawarna (2011:4) berpendapat PTK pada dasarnya memiliki sejumlah karakteristik atau ciri-ciri yaitu : 1) Bersifat siklus atau berulang, artinya dalam PTK terdapat siklus-siklus atau perulangan mulai dari perencanaan, pemberian tindakan, pengamatan dan refleksi, sebagai prosedur baku PTK, 2) Bersifat jangka panjang atau longitudinal, artinya PTK harus berlansung dalam jangka waktu lama misalnya 2-3 bulan secara kontinu untuk memperoleh data yang diperlukan, 3) Bersifat particularspesifik, jadi bermaksud melakukan generalisasi dalam rangka menguji atau menemukan teori-teori, 4) Bersifat partisipatoris, dalam arti guru sebagai peneliti sekaligus pelaku perubahan dan sasaran yang perlu diubah. Ini berarti guru berperang ganda yakni sebagai orang yang meneliti sekaligus yang diteliti, 5) Bersifat emik bukan etika artinya PTK memandang pembelajaran menurut sudut pandang orang dalam yang tidak berjarak dengan peneliti, bukan menurut sudut pandang orang luar yang berjarak dengan hal yang diteliti, 6) Bersifat kaloboratif dan kooperatif, artinya dalam pelaksanaan PTK selalu terjadi kerja 
sama atau kerja bersamaantar peneliti (guru/dosen) dan pihak lain demi keabsahan dan tercapainya tujuan penelitian, 7) Bersifat kausistik, artinya PTK menggarap kasuskasus spesifik atau khusus dalam pembelajaran yang sifatnya nyata dan terjangkau oleh guru, menggarap masalahmasalah, yang memiliki urgensi tinggi, 8) Menggunakan konteks alamiah kelas, artinya kelas sebagai ajang pelaksanaan PTK tidak perlu manipulasi atau direkayasa demi kebutuhan, kepentingan dan tercapainya tujuan penelitian, 9) Mengutamakan adanya kecukupan data yang diperlukan untuk mencapai tujuan penelitian, bukan kerepresentasifan (keterwakilan jumlah) sampel secara kuantitatif. Sebab itu, PTK hanya menuntut penggunaan statistik yang sederhana, bukan yang rumit, 10) Bermaksud merubah kenyataan dan situasi pembelajaran menjadi lebih baik dan memenuhi harapan, bukan bermaksud membangun teori dan menguji hipotesis.

Menurut Arikunto (2013:61). Tujuan Penelitian Tindakan Kelas (PTK) antara lain: a) meningkatkan mutu isi, masukan, proses, serta hasil pendidikan dan pembelajaran di sekolah, b) membantu guru dan tenaga kependidikan lainnya mengatasi masalah pembelajaran dan pendidikan di dalam dan di luar kelas, c) meningkatkan sikap professional pendidik dan tenaga kependidikan, d) menumbuh kembangkan budaya akademik di lingkungan sekolah sehingga tercipta sikap proaktif di dalam melakukan perbaikan mutu pendidikan dan pembelajaran secara berkelanjutan (sustainable).

Istilah yang sering digunakan selain Pendidikan Pancasila dan Kewarganegaraan adalah civics. Sumantri (2001:281) merumuskan pengertian Civics sebagai ilmu kewarganegaraan yang membicarakan hubungan manusia dengan: (a) perkumpulan yang terorganisir (organisasi sosial, organisasi ekonomi, dan organisasi politik); dan (b) individu dengan negara. Istilah lain yang hampir sama maknanya dengan civics adalah citizenship. Pendidikan Kewarganegaraan merupakan satu dari lima tradisi Pendidikan Ilmu Pengetahuan Sosial yaitu Citizenship tranmission, saat ini sudah berkembang menjadi tiga aspek Pendidikan Kewarganegaraan (citizenship education), yaitu aspek akademis, aspek kurikuler dan aspek sosial budaya. Pendidikan Kewarganegaraan secara akademis dapat didefinisikan sebagai suatu bidang kajian yang memusatkan telaahannya pada seluruh 
Peningkatan hasil belajar PKn

Lukcy Susilo

dimensi psikologis dan sosial budaya kewarganegaraan individu. Malik Fajar (2004:6-8) juga mengemukakanbahwa Pendidikan Kewarganegaraan sebagai wahana untuk mengembangkan kemampuan, watak dan karakter warganegara yang demokratis dan bertanggungjawab, Pendidikan Kewarganegaraan memiliki peranan yang amat penting.

Uno (2007:26) mengemukakan bahwa bermain peran merupakan metode pembelajaran yang bertujuan untuk membantu siswa menentukan makna diri (jati diri) di dunia sosial dan memecahkan dilema dengan bantuan kelompok, yang atinya melalui bermain peran siswa belajar menggunakan konsep peran, menyadari adanya peran-peran yang berbeda dan memikirkan perilaku dirinya dan perilaku orang lain. Prosedur pembelajaran melalui bermain peran tergantung kualitas permainan peran (enacment) yang diikuti analisis terhadapnya.

Role Play pada prinsipnya merupakan metode untuk menghadirkan peran yang ada dalam dunia nyata kedalam suatu pertunjukan peran di dalam kelas yang dapat dijadikan sebagai bahan refleksi agar peserta dapat memberikan penilaian, misalnya menilai keunggulan maupun kelemahan masing-masing peran tersebut kemudian memberikan saran atau alternatif.

Hal yang penting dalam role play adalah seorang anak dapat mengembangkan potensi spiritual, emosional, intelektual, sosial, bahasa dan juga fisiknya. Role play (2012:180) adalah bentuk permainan dimana seorang anak dapat menjadi apa saja yang memiliki seperangkat prilaku tertentu yang unik, seperti guru, orang tua, tokoh-tokoh masyarakat dan sebagainya.

Hamalik (2002:215) membagi tahaptahap pelaksanaan pembelajaran Role Playing menjadi empat bagian, dijelaskan sebagai berikut :

a) Menyusun rancangan tindakan perencanaan (planning)

Peneliti menyiapkan situasi-situasi masalah yang bisa dijadikan sosiodrama yang menitikberatkan pada jenis peran, masalah dan situasi familier, serta pentingnya bagi siswa. Keseluruhan situasi harus dijelaskan, yang meliputi deskripsi tentang keadaan peristiwa, individu-individu yang dilibatkan dan posisi-posisi dasar yang diambil oleh pelaku khusus. Latihan-latihan ini dirancang untuk menyiapkan siswa dan membantu mereka mengembangkan imajinasinya, dan untuk membentuk kekompakan kelompok dan interaksi. 
b) Perencanaan tindakan pelaksanaan (acting)

Pada tahap ini para siswa mulai beraksi secara spontan, sesuai dengan peran masing-masing. Mereka berusaha memainkan setiap peran seperti benar-benar dialaminya. Pemeran dapat berhenti apabila ada siswa telah merasa cukup, dan apa yang seharusnya mereka perankan telah dicoba lakukan. Adakalanya para siswa keasyikan bermain peran sehingga tanpa disadari telah memakan waktu yang telalu lama. Dalam hal ini peneliti perlu menilai kapan bermain peran dihentikan. Pemeranan dapat dihentikan pada saat terjadi pertentangan agar memancing permasalahan untuk di diskusikan.

c) Pengamatan (observing)

Pada bagian pengamatan ini dilakukan oleh pengamat, kegiatan ini berangsung pada saat acting dilakukan. Pengamat bertugas mengamati setiap karakter secara saksama yang diperankan dan berupaya menanggapi tujuan dari bermain peran dan analisis pendapat.

d) Tindakan refleksi (reflecting)

Siswa memberikan keterangan, baik secara tertulis maupun dalam kegiatan diskusi tentang keberhasilan dan hasil-hasil yang dicapai dalam bermain peran. Siswa diperkenankan memberi komentar tentang bermain peran yang telah dilaksanakan, misalnya tentang makna bermain peran bagi mereka, cara-cara yang telah dilakukan selam bermain peran, dan cara-cara meningkatkan efektivitas bermain peran selanjutnya.

Penelitian yang dilakukan adalah penelitian tindakan (action research) dengan model Kemmis and Mc.Taggart, dimana alternatif tindakan yang dipilih adalah metode pembelajaran Role Playing, sebagai upaya untuk meningkatkan hasil belajar siswa tentang pahlawanku. Metode pembelajaran role playing dirancang untuk memperbaiki dan menghasilkan pembelajaran terintegrasi dan kontekstual, khususnya dalam upaya untuk meningkatkan hasil belajar tentang pahlawankupada siswa kelas IV SDNegeri 009 Sesayap Kabupaten Tana Tidung.

\section{METODE}

Tujuan penelitian tindakan kelas ini adalah untuk memperoleh data empirik tentang peningkatan hasil belajar pendidikan pancasila dan kewarganegaraan tentang pahlawanku melalui metode role playingpada siswa kelas IV SDN 009 Sesayap Kabupaten Tana Tidung. 
Penelitian ini merupakan penelitian tindakan kelas (classroom action research). Desain intervensi tindakan/rancangan siklus dalam penelitian ini menggunakan model Kemmis dan Mc.Taggart, dengan menggunakan sistem spiral yang dimulai dari perencanaan (planning), tindakan (acting), pengamatan (observing), refleksi (reflecting), dan dilanjutkan lagi ke perencanaan kembali (replanning) sebagai dasar untuk strategi pemecahan masalah.

Penelitian tindakan ini dilakukan melalui dua siklus, yang disesuaikan dengan kondisi dan hasil refleksi ketercapaian peningkatan yang diharapkan pada siklus sebelumnya, sesuai dengan tindakan yang dilakukan. Pada siklus pertama belum berhasil, maka dilanjutkan pada siklus berikutnya.

Pada tahapperencanaan tindakan yang meliputi perencanaan umum dan perencanaan khusus. Perencanaan umum meliputi perencanaan waktu pelaksanaan penelitian yang akan dilakukan selama kurang lebih dua bulan. Peneliti mengadakan pertemuan dengan kepala sekolah untuk konsultasi, dan pertemuan dengan rekan sejawat peneliti untuk mendiskusikan langkah-langkah pelaksanaan penelitian. Selain itu direncanakan pengaturan kondisi kelas, persiapan materi pelajaran serta media/alat pembelajaran yang diperlukan, pembuatan kisi-kisi instrumen observasi tindakan, dan kisi-kisi instrumen hasil belajar siswa tentang pahlawanku.

Adapun perencanaan khusus disesuaikan dengan jadwal pembelajaran dan disusun dalam tiap pelaksanaan tindakan. Dalam hal ini peneliti membuat rencana pembelajaran sesuai Kurikulum yang berlaku, menyiapkan media pembelajaran yang diperlukan pada setiap pelaksanaan tindakan, menyiapkan lembar observasi tindakan dan instrumen evaluasi hasil belajar siswa tentang pahlawanku, serta pengumpulan data lainnya berkaitan dengan penelitian ini.

Tahapan pelaksanaan tindakan merupakan realisasi tindakan pada dasarnya disesuaikan dengan setting tindakan yang telah ditetapkan dalam rencana pelaksanaan pembelajaran (RPP). Tindakan dilaksanakan sejalan dengan langkah-langkah metode pembelajaran role playing yang telah direncanakan, untuk meningkatkan hasil belajar siswa tentang pahlawanku. Penelitian tindakan ini dilaksanakan dalam dua siklus, masing-masing siklus dilakukan 2 kali tindakan dengan alokasi waktu 1 kali tindakan adalah 2 x 35 menit sesuai dengan program pembelajaran. 
Instrumen pengumpulan data yang digunakan sebagai bahan penilaian terhadap kegiatan proses dan hasil belajar siswa adalah menggunakan instrumen pengumpulan data yang telah dipersiapkan, seperti tes hasil belajar Pendidikan Pancasila dan Kewarganegaraan dan berupa lembar observasi/pengamatan ketika menjalankan metode role playing (bermain peran). Oleh sebab itu teknik penilaian yang digunakan disesuaikan dengan objek yang dinilai dan disesuaikan dengan tujuan penilaian. Untuk menilai aktivitas proses dan hasil belajar siswa, teknik penilaian yang dipergunakan adalah dengan mengumpulkan data dengan menggunakan tes hasil belajar berupa tes soal uraian serta lembar penilaian berupa lembar observasi/pengamatan.

Kegiatan observasi (observing) dilakukan bersamaan dengan pelaksanaan tindakan yang bertujuan untuk mengenali, merekam dan mendokumentasikan proses pembelajaran yang terjadi, berkenaan dengan kegiatan guru dan siswa selama tindakan dilakukan. Observer mengamati pelaksanaan kegiatan pembelajaran dengan menggunakan lembar observasi aktivitas guru dan siswa, sambil merekam atau mendokumentasikannya. Hasil rekaman dan dokumentasi penting dilakukan agar data yang diperlukan dalam penelitian ini dapat dijaring secara lengkap dan akurat. Selain itu peneliti mencatat semua peristiwa atau hal yang terjadi di kelas selama proses pembelajaran berlangsung.

Tahapan refleksi tindakan merupakan upaya mengkaji secara menyeluruh tindakan yang telah dilakukan, berdasarkan data yang telah terkumpul, kemudian melakukan evaluasi untuk menyempurnakan tindakan berikutnya. Tahapan ini yang dilakukan oleh peneliti dan kolaborator setelah pelaksanaan tindakan. Kegiatan refleksi dilakukan secara kolaboratif, dengan mendiskusikan hasil analisis lembar observasi, catatan lapangan, serta faktor penyebab permasalahan lainnya yang terjadi selama pembelajaran di kelas. Hasil refleksi ini menjadi acuan revisi untuk menentukan perencanaan kembali (replanning) pada siklus berikutnya.

Peneliti dan kolaborator mengevaluasi kekurangan atau kelemahan serta kemajuankemajuan yang diperoleh guru dan siswa. Selain itu dalam kegiatan refleksi, dilakukan juga perbandingan antara hasil belajar siswa tentang tema pahlawanku, sebelum dan sesudah diberikan tindakan. Apabila belum terjadi peningkatan hasil belajar siswa, maka penelitian dilanjutkan pada siklus berikutnya. Setelah beberapa siklus 
dilakukan dan telah terjadi peningkatan hasil belajar, tentang tema pahlawanku sesuai dengan kriteria yang akan dicapai, maka peneliti dapat mengakhiri penelitian.

Selanjutnya pada siklus berikutnya dilaksanakan berdasarkan analisis data hasil observasi, pemaknaan data hasil observasi, penjelasan hasil analisis dan kesimpulan mengenai presentase teratasi atau tidaknya permasalahan dalam pembelajaran, serta faktor-faktor lainnya yang menjadi petimbangan belum tercapainya target dalam penelitian ini.

\section{HASIL}

Dilihat dari hasil analisis data selama tindakan mulai siklus I sampai siklus II terlihat adanya peningkatan dari semua data yang diambil. Data tes berupa skor dalam memahami makna dan keterkaitan simbolsimbol sila pancasila dalam memahami pancasila secara utuh melalui metode role playingmangalami peningkatan, dan hasil analisisnya dapat dilihat pada perkembangan hasil yang dicapai mulai dari siklus I meliputi data hasil observasi yang diperoleh dari lembar observasi tindakan guru dan siswa.

Hasil pada siklus I pertemuan pertama lembar observasi guru dalam pembelajaran role playing mencapai $33,33 \%$ dan kemudian menjadi 44,44\%. Hasil pada siklus I pertemuan pertama lembar observasi siswa dalam pembelajaran role playing mencapai 44,44\% dan kemudian menjadi $76,92 \%$. Peningkatan ini menunjukkan bahwa metode role playing yang diterapkan pada proses pembelajaran ini dapat membuat perubahan yang cukup bagi keberhasilan guru dalam proses pembelajarannya.

Selanjutnya pada hasil instrumen tes siklus I dengan presentase ketuntasan belajar adalah 50\%, memahami makna dan keterkaitan simbol-simbol sila pancasila dalam memahami pancasila secara utuh melalui metode role playingyaitu 6 siswa mendapat nilai 50-59 (20\%), 9 siswa mendapat nilai 60-69 (30\%), 9 siswa mendapat nilai 70-79 (30\%), 5 siswa mendapat nilai 80-89 (16,67\%), 1 siswa mendapat nilai 90-100 (3,33\%).

Hal ini masih menunjukkan bahwa keberhasilan siswa dalam mencapai mata pelajaran PKn masih jauh dari harapan. Untuk meningkatkan kemampuan memahami makna dan keterkaitan simbolsimbol sila pancasila dalam memahami pancasila secara utuh melalui metode role playing, maka siswa dilatih untuk lebih aktif dan menghayati pemeranannya dalam permainan role playing. Selain siswa dilatih 
untuk berdiskusi dengan kelompoknya dan bekerja sama untuk salingmemperbaiki pemeranannya dalam permainan tersebut. Pada tindakan siklus I ini siswa belum terbiasa bermain peran dalam berdiskusi dengan teman lainnya dengan satu kelompok sehingga mereka kelihatannya masih bingung. Dengan demikian hasil dari proses pembelajaran dan hasil tes pada siklus I ini masih jauh dari target yang diharapkan pada penelitian ini.

Selanjutnya pada siklus II, siswa diberikan motivasi dalam meningkatkan pemeranannya dalam permainan role playing dan memberikan latihan yang maksimal terhadap kelompok masingmasing pemeran. Setiap kelompok di berikan motivasi hadiah berupa buku bacaan dan alat-alat tulis bagi kelompok yang tampil lebih bagus dari siklus sebelumnya yakni siklus I. Dengan adanya pemberian hadiah ini siswa berlomba-lomba untuk tampil lebih bagus dan penuh semangat. Dengan demikian hasil yang diperoleh pada siklus II meningkat.

Hasil pada siklus II pertemuan pertama lembar observasi guru dalam pembelajaran role playing mencapai $66,66 \%$ dan kemudian menjadi 100\%. Hasil pada siklus II pertemuan pertama lembar observasi siswa dalam pembelajaran role playing mencapai $66,66 \%$ dan kemudian menjadi $100 \%$.

\section{PEMBAHASAN}

Peningkatan ini menunjukkan bahwa metode role playing yang diterapkan pada proses pembelajaran ini dapat membuat perubahan yang cukup bagi keberhasilan guru dalam proses pembelajarannya.

Selanjutnya pada hasil instrumen tes siklus II dengan presentase ketuntasan $80 \%$, memahami makna dan keterkaitan simbolsimbol sila pancasila dalam memahami pancasila secara utuh melalui metode role playingyaitu 3 siswa mendapat nilai 50-59 (10\%), 3 siswa mendapat nilai 60-69 (10\%), 6 siswa mendapat nilai $70-79(20 \%), 15$ siswa mendapat nilai $80-89$ (50\%), 1 siswa mendapat nilai 90-100 (33,33\%).

Dengan demikian hasil yang telah meningkat secara signifikan pada siklus II ini sebagaimana harapan peneliti telah tercapai, maka penelitian ini tidak dilanjutkan lagi karena telah mencapai hasil yang diharapkan. Namun terdapat 6 siswa tidak tuntas karena mencapai nilai yang dicapai pada siklus II di bawah KKM. 
Peningkatan hasil belajar PKn

Lukcy Susilo

\section{KESIMPULAN}

Berdasarkan hasil penelitian tindakan tentang peningkatan hasil belajar PKn melalui metode role playing pada siklus I dan siklus II menghasilkan kesimpulan sebagai berikut:

Peningkatan kemampuan memahami makna dan keterkaitan simbol-simbol sila pancasila dalam memahami pancasila secara utuh melalui metode role playingdengan meningkatkan pemahaman dan penghayatan siswa terhadap perannya dalam pembelajaran.

Hasil observasi menunjukkan bahwa simulasi tentang kemampuan memahami makna dan keterkaitan simbol-simbol sila pancasila dalam memahami pancasila secara utuh melalui metode role playingdengan meningkatkan kemampuan siswa dalam memimpin, membuat keputusan yang dapat diterima oleh teman lainnya, mengaktifkan siswa dalam diskusi kelompok, menerima dan menghargai perbedaan pendapat, melakukan musyawarah untuk mencapai mufakat, meningkatkan rasa tanggung jawab terhadap tugas yang diembankan, meningkatkan persahabatan dan kerjasama yang baik antar sesama siswa dalam kelompok dan saling membantu untuk pelaksanaan hasil keputusan.
Pembelajaran role playing dapat meningkatkan kegairahan siswa dalam pembelajaran sehingga mengurangi kejenuhan siswa dalam menerima pelajaran. Dalam pembelajaran perlu diberikan reward atas penghargaan kepada siswa yang berhasil sebagai motivasi bagi siswa lainnya untuk meningkatkan hasil belajar yang dikehendaki.

Hasil belajar siswa dari siklus I dan siklus II meningkat secara signifikan dengan KKM 70. Hasil siklus I dari 30 siswa hanya 15 orang yang dinyatakan lulus, dengan rata-rata kelas 69 presentase $50 \%$. Kemudian perbaikan pembelajaran metode role playing dilanjutkan pada siklus II dengan rata-rata kelas 77 presentase $80 \%$ mengalami peningkatan dari siklus I. Dari jumlah 30 orang hanya 6 orang siswa yang tidak tuntas.

\section{DAFTAR RUJUKAN}

Ahmadi, Khoiru, Sofan Amri, Hendro Ari Setyono dan Tatik Elisah. 2013 Strategi Pembelajaran Berorientasi KTSP. Jakarta: Prestasi Pustakaraya. Arikunto, Suharsimi. 2013. Dasar-dasar Evaluasi Pendidikan. Jakarta: Bumi Askara.

Ekawarna. 2011. Penelitian Tindakan Kelas. Jakarta: Gaung Persada Perss 
JURNAL PENDIDIKAN DASAR

Volume 6 Edisi 1 Mei 2015

Hamalik, Oemar. 2010. Proses Belajar Mengajar. Jakarta: PT Bumi Askara

Mulyasa, E. 2012. Manajemen Pendidikan Karakter. Jakarta: PT Bumi Askara, Fajar, Malik. 2004. Pendidikan Pancasila dan Kewarganegaraan. Jakarta: Gramedia.
Uno, Hamzah B., 2007. Model Pembelajaran Menciptakan Proses Belajar Mengajar yang Kreatif dan Efektif. Jakarta: Bumi Askara.

Sumantri. 2001. Pendidikan Pancasila dan Kewarganegaraan (Civic).Jakarta: Grasindo. 